ISAHP Article: Mu, Saaty/A Style Guide for Paper Proposals To Be Submitted to the International Symposium of the Analytic Hierarchy Process 2014, Washington D.C., U.S.A.

\title{
Ranking Critical Success Factors of Healthcare Management Information Systems using AHP
}

\author{
Nizar Hussain M \\ Department of Mechanical Engineering \\ TKM College of Engineering, Kollam 691005, Kerala, India \\ E-mail: nizarhussainm@gmail.com \\ Suresh Subramoniam \\ Department of Business Administration \\ College of Engineering, Trivandrum 695016, Kerala, India \\ E-mail: sreshsubramoniam@gmail.com
}

\begin{abstract}
The ranking of Critical Success Factors (CSF) of Healthcare Management Information System (HMIS) help practitioners to identify vital factors from the trivial many that are essential for its success. The objective of this study is to rank the CSF of HMIS using a suitable Multi-Criteria Decision Making technique (MCDM). Here, Analytic Hierarchy Process (AHP) is the MCDM used to determine the relative importance of the CSF in influencing the adoption and use of HMIS. In order to rank the factors, this study is planned and performed in two stages. At the first stage to identify the critical success factors of HMIS, a through literature review is made. At the second stage, a pair wise comparison is designed based on AHP method to collect the opinions of experts and distributed among 15 persons of the organizational experts/academicians. The pairwise comparisons got from this stage are analysed by AHP. The research findings indicate that the critical success factors in HIS have different priorities and weights. The weightage got from AHP can also be used for ranking of various HMIS installations in different hospitals.
\end{abstract}

Keywords: Critical Success Factors, Healthcare Management Information System, Multi Criteria Decision Making, Analytic Hierarchy Process. 


\section{Introduction}

Critical Success Factors (CSF) are those measures which have direct bearing on the success of an organization (Ketelhohn 1998). The CSF are related to subjects which are important for the success of an organization. Every organization has an unique environment, therefore identifying the critical factors of Hospital Information System (HIS) which are common to several such implementations has been the subject of previous studies (Hanafizade and Ghafori 2007). Identifying and ranking the critical success factors in this research propose to give a solution for the ranking of various HIS installations in different hospitals.

This research aims at identifying CSF for the HIS implementation. An effective tool is required for identifying and prioritizing relevant criteria and sub-criteria. Analytic Hierarchy Process (AHP), Multi Criteria Decision Making (MCDM) technique proposed by Saaty (1987) is used for ranking in this research. The main strength of this study is the application of a formal method for ranking CSF in HIS implementation. The presentation about this study is organized as follows. Section 2 presents an extensive literature review on the topic followed by review of methodology as given in Section 3. Analytic Hierarchy Process methodology is briefly dealt with in the Section 4. The AHP modeling of the study and findings are dealt in Section 5 before discussing managerial implications and conclusions in Section 6 and Section 7, respectively .

\section{Literature review}

\subsection{Healthcare Information System}

The term HIS used here is synonymous with Healthcare Planning System and Hospital Information System. Its development dates back to 1960 with its limited domain of use in administration alone. In the late 1970s, big hospitals gradually set up internal information sectors and subsequently, private information companies started to develop information systems with high commercial value which fostered development of the HIS to its present state (Tsai et al. 2004). The development of the system engulfed healthcare diagnosis, symptoms, cause analysis, healthcare target and measurements. Such systems provide healthcare professionals with the necessary contents, healthcare plans, and additional functions including addition, revision, inquiry and printing (Mehmart et al. 1987). Simpson and Weaver (2005) state that by integration of the hospital system, clinical care and administration in the HIS enhances the efficiency of the system. Many scholars have adopted different methods to evaluate the efficiency of such systems. Hortman and Thompson (2005) carried out surveys using both questionnaires and forms to identify user's satisfaction and opinion, while Lee et al. (2002) used one-to-one or one-to-many quality interviews to carry out in-depth analysis of the user's opinion about a system. HIS has been evaluated using questionnaire surveys, in-depth interviews, individual case studies or material collections. The questionnaire method is most widely used one which is generally targeted at user satisfaction and attitudes relevant to demographic characteristics like respondent's age, seniority, education, and satisfaction (Lee et al. 2005, Alquraini et al. 2007). In recent years, the application of HIS, CSF in its implementation and relevant research results are gaining prominence to improve systems and their performance.

\subsection{Critical Success Factors}

Critical Success Factors (CSF) can be defined as key areas of performance that are essential for the organization to accomplish its mission. CSF are those relatively few things that must be accomplished for the individual or the organization to be considered successful by important stakeholders. CSF are important to identify and understand because they focus attention on the things that matter most rather than on the trivial things that consume most of the manager's time (Stahl and Michael, 2004). A broad range of factors that can influence the success of HIS have been mentioned in the literature. This section consists of the details of empirical studies carried out previously on success factors area which support the current research theoretically to derive 
the critical success factors for the HIS. Perceived usefulness is the most frequent success factor encountered in the literature (29 studies). Ease of use was the second most significant success factor (17 studies). Attitude has been considered highly relevant in 9 studies, Self efficacy and Training in 7 studies each, top management support in 8 studies and facilitating conditions in 9 studies, System Reliability and Information quality, Service care quality in 5 studies each are all other factors determining the success of HIS implementation. Summary of reviewed articles is shown in Table 1.

Table 1. Summary of reviewed articles

\begin{tabular}{|c|c|c|}
\hline $\begin{array}{l}\text { CSF related } \\
\text { to HIS }\end{array}$ & $\begin{array}{l}\text { Number } \\
\text { of } \\
\text { studies }\end{array}$ & References \\
\hline $\begin{array}{l}\text { Perceived } \\
\text { usefulness }\end{array}$ & 29 & $\begin{array}{l}\text { Al Farsi (2006), Connelly et al. (1992), Crowe and Sim (2004), D'Alessandro et al. } \\
\text { (2004), Eley et al. (2005), Firby et al. (1991), Galligioni et al. (2009), Hier et al. } \\
\text { (2004), Hou et al. (2006), Joos et al. (2006), Jousimaa et al. (1998), Kamadjeu et al. } \\
\text { (2005), Keshavje et al. (2001), Kouri et al. (2005), Larcher et al. (2003), Marcy et al. } \\
\text { (2008), Magrabi et al. (2007), Martinez et al. (2007), O'Connell et al. (2004), } \\
\text { Ovretveit et al. (2007), Pagliari et al. (2003), Pare and Sicotte (2006), Popernack } \\
\text { (2006), Pourasghar et al. (2008), Soar et al. (1993), Thoman et al. (2001), } \\
\text { Vanmeerbeek (2004), Whittaker et al.(2009), Zheng et al.(2005) }\end{array}$ \\
\hline $\begin{array}{l}\text { Perceived } \\
\text { ease of use }\end{array}$ & 17 & $\begin{array}{l}\text { Connelly et al. (1992), Di Pietro (2008), Eley et al. (2005), Galligioni et al. (2009), } \\
\text { Haynes et al. (1990), Kouri et al. (2005), Likourezo et al. (2004), Ovretveit et al. } \\
\text { (2007), Pagliari et al. (2003), Pare and Sicotte (2006), Pourasghar et al. (2008), Pugh } \\
\text { et al.(1994), Soar et al. (1993), Vanmeerbeek (2004), Verhoeven et al.(2009), } \\
\text { Whittaker et al.(2009), Zheng et al.(2005). }\end{array}$ \\
\hline Attitude & 9 & $\begin{array}{l}\text { Eley et al. (2005), Firby et al. (1991), Haynes et al. (1990), Hier et al. (2004), Larcher } \\
\text { et al. (2003), Lee et al. (2009), O'Connell et al. (2004), Thoman et al. (2001), Crosson } \\
\text { et al. (2008) }\end{array}$ \\
\hline Self efficacy & 7 & $\begin{array}{l}\text { Cheng (2003), Firby et al. (1991), Yeh etal. (2009), Torkzadeh et al. (2002), Barbeite } \\
\text { et al. (2004), Bedard et al. (2003), Hasan (2003). }\end{array}$ \\
\hline Training & 7 & $\begin{array}{l}\text { Barsukiewicz (1998), Cheng (2003), Haynes et al. (1990), Joos et al. (2006), Keshavje } \\
\text { et al. (2001), Lai (2006), Marcy et al. (2008) }\end{array}$ \\
\hline $\begin{array}{l}\text { Management } \\
\text { support }\end{array}$ & 8 & $\begin{array}{l}\text { Haynes et al. (1990), Hou et al. (2006), Keshavje et al. (2001), Kouri et al. (2005), } \\
\text { Lapointe (2006), O'Connell et al. (2004), Pare and Sicotte (2006), Travers and } \\
\text { Parham (1997) }\end{array}$ \\
\hline $\begin{array}{l}\text { Facilitating } \\
\text { conditions }\end{array}$ & 9 & $\begin{array}{l}\text { Al Farsi (2006), Haynes et al. (1990), Joos et al. (2006), Jousimaa et al. (1998), Pugh } \\
\text { et al.(1994), Soar et al. (1993), Ovretveit et al. (2007), Walji et al. (2009), Cumbers } \\
\text { and Donald (1998) }\end{array}$ \\
\hline $\begin{array}{l}\text { System } \\
\text { reliability }\end{array}$ & 5 & $\begin{array}{l}\text { Connelly et al. (1992), Galligioni et al. (2009), Joos et al. (2006), Kouri et al. (2005), } \\
\text { Rahimi et al. (2009) }\end{array}$ \\
\hline $\begin{array}{l}\text { Information } \\
\text { quality }\end{array}$ & 5 & $\begin{array}{l}\text { Chisolm et al. (2006), Hains et al. (2009) Pugh et al.(1994), D'Alessandro et al. } \\
\text { (2004), Lai (2006), 79, } 97\end{array}$ \\
\hline $\begin{array}{l}\text { Service care } \\
\text { quality }\end{array}$ & 5 & $\begin{array}{l}\text { DeLone et al. (2003), Gillingham et al. (2002), Lu, et al. (2005), Sarker et al. (2005), } \\
\text { Varshney (2003) }\end{array}$ \\
\hline
\end{tabular}

The present study considers ten factors that were adopted from literature. These include Perceived usefulness, Perceived ease of use, Attitude, Self efficacy, Training, Top management support, Facilitating conditions, System reliability, Information quality and Service care quality. Summary of factors and its definitions are in Table 2 (Venkatesh and Davis, 2000; Venkatesh et al., 2003; Chau, 2001; Goodhue and Thompson ,1995; Igbaria and Iivari, 1995; Bhattacherjee and Hikmet, 2008; Sutirtha Chatterjee et.al., 2009; Seddon and Kiew,1996; Brady et. al., 2002).

Table 2. Summary of factors and the corresponding definitions

\begin{tabular}{|c|}
\hline $\begin{array}{l}\text { International Symposium of } \\
\text { the Analytic Hierarchy }\end{array}$ \\
\hline
\end{tabular}




\begin{tabular}{|l|l|}
\hline \multicolumn{1}{|c|}{ Factors } & \multicolumn{1}{c|}{ Description of the factor } \\
\hline $\begin{array}{l}\text { Perceived } \\
\text { usefulness (PU) }\end{array}$ & $\begin{array}{l}\text { The degree to which a person believes that using a particular computer system would enhance his or her } \\
\text { job performance. }\end{array}$ \\
\hline $\begin{array}{l}\text { Perceived ease of } \\
\text { use (PEOU) }\end{array}$ & The degree to which a person believes that using a particular computer system would be free of effort. \\
\hline Attitude & User's affection, or liking, for HIS and for using them. \\
\hline Self Efficacy & An individual's perception of his or her ability to use a computer system in accomplishing a job task. \\
\hline Training & Extent to which an individual has been trained about HIS through courses, training, manuals, and so on \\
\hline $\begin{array}{l}\text { Management } \\
\text { support }\end{array}$ & Top-management support for, and favorable attitude toward, HIS in general. \\
\hline $\begin{array}{l}\text { Facilitating } \\
\text { conditions }\end{array}$ & $\begin{array}{l}\text { The adequacy of the deployment of IT infrastructure (such as network, server, and database) in an } \\
\text { organization to support job performance and to improve the quality of the users job. }\end{array}$ \\
\hline $\begin{array}{l}\text { System reliability } \\
\text { The extent to which the system can be depended upon to complete a task without problems and } \\
\text { breakdowns. }\end{array}$ & $\begin{array}{l}\text { Degree to which information produced has the attributes of accuracy, format, completeness, } \\
\text { understandability, and report timeliness for the user. }\end{array}$ \\
\hline $\begin{array}{l}\text { Information } \\
\text { quality }\end{array}$ & \begin{tabular}{l} 
Perception of how a HIS provider delivers the service to user. \\
\hline $\begin{array}{l}\text { Service care } \\
\text { quality }\end{array}$
\end{tabular} \\
\hline
\end{tabular}

\section{Methodology Review}

A number of methods have been applied to HIS or other information system (IS) evaluation or selection including ranking, scoring, mathematical optimization, and MCDM analysis. Buss (1983) proposed a ranking approach to compare computer projects. The scoring (Lucas and Moore, 1976) method is intuitive, but too simple to truly reflect opinions of the decision makers. Mathematical optimization such as goal programming, 0-1 programming, and nonlinear programming have been applied to resource optimization for IS selection. Santhanam and Kyparisis (1995) proposed a nonlinear programming model to optimize resource allocation allowing for the interaction of factors; their model considered interdependencies between projects in the IS selection process. Lee and Kim (2000) claimed that Santhanam and Kyparisis' model dealt with IS selection problems with limited criteria. They combined the analytic network process (ANP) and a 0-1 goal-programming model to select an IS project. However, the applicability of these methods is often weakened by sophisticated mathematic models or limited attributes to carry out in a real-world HIS selection decision, especially when some attributes are not readily quantifiable, as well as not too easy for managers to understand. The AHP method, introduced by Saaty (1980), directs how to determine the priority of a set of alternatives and the relative importance of attributes in a MCDP, and has been widely discussed in various aspects. For example, Schniederjans and Wilson (1991) utilized the AHP method to determine the relative weights of attributes and applied these weights to a goal programming model for IS selection. Lai et al. (1999) conducted a case study to select a multimedia authoring system using the AHP method. Teltumbde (2000) proposed a framework based on the nominal group technique and AHP to select an ERP system. Jose et al (2005) used the AHP method to rank critical success factors of executive information system. Loannis et al. (2011) proposes a methodology for creating an evaluation system of the passenger ferry services on the basis of key performance indicators derived through the analytic hierarchy process. But no study is found in the literature which makes use of AHP for ranking CSF of HIS. This has prompted the authors of this research to rank CSF of HIS using AHP.

\section{Analytic Hierarchy Process based methodology}

AHP is used widely for various ranking applications based on MCDM and the technique is made use of here for ranking various HIS based on user preferences. 
IJAHP Article: Mu, Saaty/A Style Guide for Paper Proposals To Be Submitted to the International Symposium of the Analytic Hierarchy Process 2014, Washington D.C., U.S.A.

\subsection{An overview of the AHP}

The purpose of this study is to offer a business model framework for HIS. It is typical of such an approach to have decision-making problems with multi-criteria and multi-attributes. One of the optimal approaches to solve such a problem is using AHP (Saaty 1980, 1994, 2008). AHP which is a qualitative and quantitative method, is a useful approach for evaluating the alternatives of complex multiple criteria involving subjective judgment. AHP is a way that could transform complex problems into simple hierarchic structure, such as project screening (Chin et al., $\mathrm{Xu}$, Yang, an Lam, 2008), evaluation of knowledge management (Ngai and Chan 2005) and so on. A decision-maker should determine the weights by conducting pair-wise comparisons between various criteria or among sub criteria.

The main procedures of AHP are to: (i) determine the objective and the attributes of evaluation; (ii) develop hierarchical structure levels with goals, constructs, criteria or sub criteria and the alternatives; (iii) find out the importance of different attributes with respect to the goals.

\subsection{A hierarchic framework}

According to the AHP steps enumerated as above, objectives and attributes of evaluation have been determined based on reviewed the literature in Section 2, and have identified probable CSF. In order to rank the CSF related with HIS, identified CSF are classified in to four categories. They are Behavioural intention to use, Individual context, Organisational context and System context as summarized in Table 3. The hierarchy frame work is shown in Figure 1.

Table 3. Summary of Factors identified for the study

\begin{tabular}{|l|l|}
\hline \multicolumn{1}{|c|}{ Criteria } & \multicolumn{1}{c|}{ Sub-Criteria } \\
\hline Behavioral intention to use & Perceived usefulness, Perceived ease of use \\
\hline Individual context & Attitude, Self efficacy, Training \\
\hline Organisational context & Top management support, Facilitating conditions \\
\hline System context & System reliability, Information quality, Service care quality \\
\hline
\end{tabular}

International Symposium of the Analytic Hierarchy

Process
Washington, D. C. June 29 - July 2, 2014 


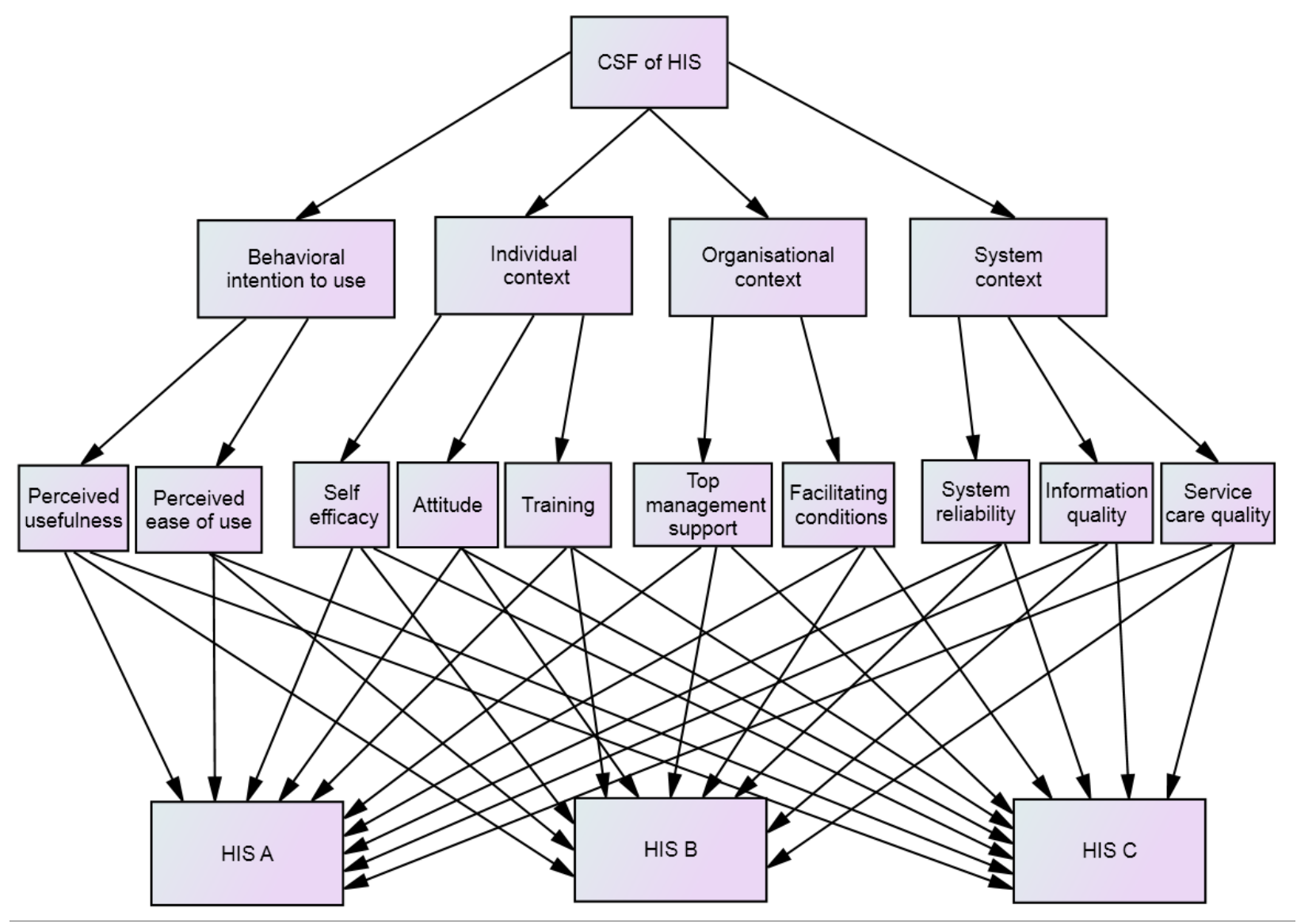

Figure 1. CSF hierarchy model

The highest level with only one element is the goal to reach and the elements in the lowest level are the factors. Elements in the middle levels are the categories/criteria/constructs for evaluating those factors. In this work, the hierarchy of all criteria and sub-criteria were classified into four levels as depicted in Figure 2. At the highest level (Level 1) of the hierarchy are CSF. It is possible to classify the CSF into four major categories, namely, Behavioural intention to use, Individual context, Organisational context and System context. This taxonomy constitutes the second level. The third level shows the specific CSF within each category. Finally, there are four major constructs obtained from ten factors as listed in Table 1. Thus, these constructs and factors had considerable degree of content validity as described in earlier studies. Based on these contents, the definition of each of the probable CSF is as given in Table 2. CSF hierarchic model is given in Figure 2. The first layer is the ultimate goal, the second layer is the main criteria and the third layer is the sub-criteria. Under this framework there are fourteen pair wise comparisons to calculate each factor's weight by AHP. Finally, offer a referential framework for the hospitals to rank different HIS. This is the fourth layer in the hierarchy. The weights for the different criteria obtained by using the analytic hierarchy process method can be subsequently used to rank HIS A, HIS B and HIS C as shown in the fourth hierarchy level.

\subsection{Pair-wise comparison matrix}

Further details for the AHP process are as follows (Saaty, 1994; Saaty \& Vargas, 2000): (a) Constructing a pair-wise comparison matrix with a scale of relative importance. An attribute compared with itself is always attributed to value 1 , so all the main diagonal entries of the pairwise comparison matrix are 1 . Numbers 3, 5, 7, and 9 mean moderate importance, strong International Symposium of 
importance, 'very important', and 'absolutely important'; and 2, 4, 6, and 8 for compromise between $3,5,7,9$. If there are $\mathrm{m}$ attributes, then the pair-wise comparisons would yield a square matrix as Matrix A, pair-wise comparison is stated as the most effective way to better judgment as only two attributes are only compared at a time (Saaty, 1994) and 1-9 judgment scale has been recommended in the literature (Saaty, 1996). Table 4 shows the pair-wise comparison scale for AHP and its interpretation.

Table 4. Pair-wise comparison table for AHP with interpretation (Saaty, 1996)

\begin{tabular}{|c|l|l|}
\hline $\begin{array}{c}\text { Intensity of } \\
\text { importance }\end{array}$ & \multicolumn{1}{|c|}{ Definition } & \multicolumn{1}{c|}{ Explanation } \\
\hline 1 & Equal importance & Two attributes contribute equally to the objective \\
\hline 3 & Weak importance & $\begin{array}{l}\text { Experience and judgment slightly favor one activity over } \\
\text { another }\end{array}$ \\
\hline 5 & Strong importance & $\begin{array}{l}\text { Experience and judgment strongly favor one activity over } \\
\text { another }\end{array}$ \\
\hline 7 & Very strong importance & An activity is favored very strongly over another \\
\hline 9 & Absolute importance & $\begin{array}{l}\text { The evidence favoring one activity over another is of the } \\
\text { highest possible order of affirmation }\end{array}$ \\
\hline $2,4,6,8$ & Intermediate values & When compromise is needed \\
\hline
\end{tabular}

The results of the comparisons are represented in a pair-wise comparison matrix which is a reciprocal matrix as shown below.

$\mathrm{A}=\left(\begin{array}{cccr}\mathrm{a}_{11} & \mathrm{a}_{12} & \ldots & \mathrm{a}_{1 \mathrm{~m}} \\ \mathrm{a}_{21} & \mathrm{a}_{22} & \ldots & \mathrm{a}_{2 \mathrm{~m}} \\ \ldots & \ldots & \ldots & \ldots \\ \ldots & \ldots & \ldots & \ldots \\ \mathrm{a}_{\mathrm{m} 1} & \mathrm{a}_{\mathrm{m} 2} & \ldots & \mathrm{a}_{\mathrm{mm}}\end{array}\right]=\left[\begin{array}{llll}1 & \mathrm{a}_{12} & \ldots & \mathrm{a}_{1 \mathrm{~m}} \\ 1 / \mathrm{a}_{12} & 1 & \ldots & \mathrm{a}_{2 \mathrm{~m}} \\ \ldots & \ldots & & \ldots \\ \ldots & \ldots & \ldots & \ldots \\ 1 / \mathrm{a}_{1 \mathrm{~m}} & 1 / \mathrm{a}_{2 \mathrm{~m}} & \ldots & 1\end{array}\right]$

where $a_{i j}=$ the relative importance of criteria $i$ compared to criteria $j ; a_{i j}=1$ where $i=j$; and $a_{j i}=$ $1 / a_{i j}$ where $i \neq j$. (b) Finding the relative normalized weight $\left(w_{j}\right)$ of each attribute by calculating the geometric mean of the $i^{\text {th }}$ row normalizes the geometric means of rows in the comparison matrix. The geometric mean method of AHP is used to find out the relative normalized weights of the attributes because of its simplicity and ease to find out the maximum eigenvalue and reduce the inconsistency in judgments. In Matrix A, the problem involves assigning a set of numerical weights $\mathrm{w}_{1}, \mathrm{w}_{2}, \ldots \ldots ., \mathrm{w}_{\mathrm{m}}$ to the $\mathrm{m}$ criteria $\mathrm{a}_{1}, \mathrm{a}_{2}, \ldots \ldots ., \mathrm{a}_{\mathrm{m}}$ that reflect the recorded judgments. If $A$ is a consistency matrix, then the relations between weights $w_{j}$ and judgments $a_{i j}$ would be simply given by $\mathrm{w}_{\mathrm{i}} / \mathrm{w}_{\mathrm{j}}=\mathrm{a}_{\mathrm{ij}}($ for $\mathrm{i}, \mathrm{j}=1,2, \ldots \ldots \ldots, \mathrm{m})$. (c) After the formation of decision making matrix, the next step is to identify the priority weights of the elements through the maximum eigenvectors and eigenvalues. According to Saaty (1994), the eigenvectors can be computed as follows. Aw can be written as $\mathbf{n w}$ where $\mathrm{n}$ is the number of eigen values or elements and $\mathrm{w}$ is the vector of actual relative weights of $\mathbf{A}$. Eigen vectors of $\lambda$ are non zero solutions of $(\mathbf{A}-\lambda \mathbf{I}) \mathbf{w}=0$ where $\mathbf{I}$ is an identity matrix. Also, $\mathbf{A w}=\lambda_{\max } \mathbf{w}$ where $\lambda_{\max }$ is the largest eigenvalue of A. (d) The consistency of the pair wise comparisons is checked in this step. In the pair wise comparison, the inconsistency is measured by consistency index (CI) and the coherence is measured by Consistency Ratio (CR) and is computed with the help of the formula, $C I=\left(\lambda_{\max }-\mathrm{m}\right) /(\mathrm{m}-1), \mathrm{CR}$ $=\mathrm{CI} / \mathrm{RI}$, where, $\mathrm{m}$ is the rank of the matrix. The maximum acceptable limit of CR is 0.1 (Saaty, 1994). If the values are more than 0.1 it will highlight that the pairwise comparison is inconsistent and hence, discarded. For different matrix size (m), the respective values of RI are depicted in Table 5. (e) After identifying the priority weights of each element, i.e. local weights of element, International Symposium of 7

Washington, D. C. the Analytic Hierarchy June 29 - July 2, 2014

Process 
the next step is to identify the global weights of all elements with respect to the goal defined in the AHP model. (f) Finally, after calculating the global weights, all the elements are rearranged in the decreasing order according to the global prioritization.

Table 5. Matrix size versus Random Index

\begin{tabular}{lcccccccccc}
\hline $\begin{array}{l}\text { Size of the } \\
\text { matrix }\end{array}$ & $\mathbf{1}$ & $\mathbf{2}$ & $\mathbf{3}$ & $\mathbf{4}$ & $\mathbf{5}$ & $\mathbf{6}$ & $\mathbf{7}$ & $\mathbf{8}$ & $\mathbf{9}$ & $\mathbf{1 0}$ \\
\hline Random Index & 0.00 & 0.00 & 0.58 & 0.90 & 1.12 & 1.24 & 1.32 & 1.41 & 1.45 & 1.49 \\
\hline
\end{tabular}

\section{Data Collection and analysis}

Ranking the factors of HIS is considered as the goal in this hierarchy and this goal forms the first level in the hierarchy. Second level consists of various constructs based on which HIS CSF are to be compared and ranked (Saaty, 2008). Third level consists of criteria which are perceived usefulness, perceived ease of use, facilitating conditions, social influence and Training. Figure 1 shows the hierarchy of the goal at Level 1, decision criteria at level 3 and the various types of HIS CSF as alternatives at Level 4.

This research collected pair wise comparisons from 15 experts and consultants in the domain of health information systems for over ten years. Consensus is reached in cases where difference of opinion existed to arrive at final Matrix of pairwise comparison values. The pair wise comparison matrix of constructs and CSF are shown in Table 6 and 7. According to the data from the pairwise comparison, factor weight of each item or factor is determined by AHP methodology. After computing, it is found that nearly all replies to the pair wise comparisons reached a consistency ratio (i.e. $\mathrm{CR}=\mathrm{CI} / \mathrm{RI}$, as described in Section 3.3) of less than 0.1, hence the decision maker's pair-wise comparison matrices are found acceptable.

Table 6. Pair-wise comparisons of major factors

\begin{tabular}{lcccc}
\hline Constructs of HIS, CR=0.0789 & $\begin{array}{c}\text { Behavioural } \\
\text { intention to use }\end{array}$ & $\begin{array}{c}\text { Individual } \\
\text { context }\end{array}$ & $\begin{array}{c}\text { Organisational } \\
\text { context }\end{array}$ & $\begin{array}{c}\text { System } \\
\text { context }\end{array}$ \\
\hline Behavioural intention to use & 1 & 4 & 4 & $1 / 2$ \\
Individual context & $1 / 4$ & 1 & $1 / 3$ & $1 / 4$ \\
Organisational context & $1 / 4$ & 3 & 1 & $1 / 3$ \\
System context & 2 & 4 & 3 & 1 \\
\hline
\end{tabular}

Table 7. Pair-wise comparisons of Sub-criteria under each Criteria

\begin{tabular}{|c|c|c|c|}
\hline Behavioural intention to use, $\mathrm{CR}=0$ & Perceived ease of use & Perceived usefulness & \\
\hline Perceived ease of use & 1 & 2 & \\
\hline Perceived usefulness & $1 / 2$ & 1 & \\
\hline Individual context, $\mathrm{CR}=\mathbf{0 . 0 5 1 5 6}$ & Attitude & Efficacy & Training \\
\hline Attitude & 1 & 3 & 2 \\
\hline Efficacy & $1 / 3$ & 1 & $1 / 3$ \\
\hline Training & $1 / 2$ & 3 & 1 \\
\hline Organizational context, $\mathrm{CR}=0$ & Facilitating conditions & Top management support & \\
\hline Facilitating conditions & 1 & $1 / 2$ & \\
\hline Top management support & 2 & 1 & \\
\hline System context, $\mathrm{CR}=\mathbf{0 . 0 7 3 5}$ & Information quality & Service care quality & System reliability \\
\hline Information quality & 1 & 7 & 2 \\
\hline Service care quality & $1 / 7$ & 1 & $1 / 8$ \\
\hline System reliability & 0.5 & 8 & 1 \\
\hline
\end{tabular}


IJAHP Article: Mu, Saaty/A Style Guide for Paper Proposals To Be Submitted to the International Symposium of the Analytic Hierarchy Process 2014, Washington D.C., U.S.A.

Table 8 summarizes the local weights for each main criteria or construct, Table 9 shows construct ranking with global weights. As shown in Table 9, system context construct (0.4433) is the most valued in the second hierarchy level. It was about 1.3 times to six times greater than that of the behavioural intention to use construct $(0.3410)$, Organisational context construct (0.1430) and Individual context construct (0.0757). Table 10 shows the global weights based CSF ranking. They have been calculated by multiplying the local weights of each CSF by the global weight of each category. By doing this, each local CSF is normalised for the importance of the construct to which it belongs.

Table 8. Summary of local weights for each CSF

\begin{tabular}{|l|l|c|}
\hline \multicolumn{1}{|c|}{ Construct } & \multicolumn{1}{|c|}{ CSF } & Local weights \\
\hline \multirow{2}{*}{ Behavioural intention to use } & Perceived ease of use & 0.6600 \\
\cline { 2 - 3 } & Perceived usefulness & 0.3300 \\
\hline \multirow{3}{*}{ Individual context } & Attitude & 0.5278 \\
\cline { 2 - 3 } & Efficacy & 0.1396 \\
\cline { 2 - 3 } & Training & 0.3325 \\
\hline \multirow{2}{*}{ Organisational context } & Facilitating conditions & 0.3300 \\
\cline { 2 - 3 } & Top management support & 0.6600 \\
\hline \multirow{3}{*}{ System context } & Information quality & 0.5659 \\
\cline { 2 - 3 } & Service care quality & 0.0614 \\
\cline { 2 - 3 } & System reliability & 0.3727 \\
\hline
\end{tabular}

Table 9. Construct ranking with global weights

\begin{tabular}{|c|l|c|}
\hline Rank & Construct & Global weights \\
\hline 1 & System context & 0.4403 \\
\hline 2 & Behavioural intention to use & 0.3410 \\
\hline 3 & Organisational context & 0.1430 \\
\hline 4 & Individual context & 0.0757 \\
\hline
\end{tabular}

Table 10. CSF ranking with global weights

\begin{tabular}{|c|l|l|c|}
\hline Rank & CSF & Construct category & Global weight \\
\hline 1 & Information quality & System context & 0.2492 \\
\hline 2 & Perceived ease of use & Behavioural intention to use & 0.2251 \\
\hline 3 & System reliability & System context & 0.1641 \\
\hline 4 & Perceived usefulness & Behavioural intention to use & 0.1125 \\
\hline 5 & Top management support & Organizational context & 0.0944 \\
\hline 6 & Facilitating conditions & Organizational context & 0.0472 \\
\hline 7 & Attitude & Individual context & 0.0399 \\
\hline 8 & Training & Individual context & 0.0270 \\
\hline 9 & Service care quality & System context & 0.0252 \\
\hline 10 & Self efficacy & Individual context & 0.0106 \\
\hline
\end{tabular}

As the results in Table 10 show, the ranking of the weights of the CSF are Information quality (0.2492), Perceived ease of use (0.2251), System reliability (0.1641), Perceived usefulness 
(0.1125), Top management support (0.0944), Facilitating conditions (0.0472), Attitude (0.0399), Training (0.0270), Service care quality (0.0252) and Self efficacy $(0.0106)$. These results manifest the most influential CSF for the HIS is Information quality, and the least influential is self efficacy.

A one to one comparison between the results got in this study and that in the literature is shown in Table 11. There are some differences in the priority weights due to the fact that background and parameters of the earlier studies differ from this study in many ways. Since AHP is a relative comparison method, the priority values vary depending upon the number of parameters. At the same time the relative ranking of this study is consistent with the previous studies. It is discovered that information quality is the most significant determinant of technology acceptance. This means that the quality of the information produced by the HIS has a crucial aspect for medically related software. Given that medical software deals with lots of confidential and highly sensitive information, it is important that the software developer produces software that fulfils this criteria. This result is consistent with other previous studies (Sepahvand and Arefnezhad, 2013, Alexander, 2011, Jose et al., 2005). It is found that ease of use is the second predominant factor, as it has a direct effect on behavioural intention. Thus, this research supported the inclusion of perceived ease of use as CSF, which was supported theoretically and empirically and the result is consistent with previous studies (Alexander, 2011, Jose et al., 2005, Lesley and Glyn, 1994). Similarly, System reliability, perceived usefulness, top management support and Facilitating conditions have been ranked with the most importance with other factors following in descending order of their importance. Relatively similar importance for these factors is also reported in normative literature (Sepahvand and Arefnezhad, 2013, Alexander, 2011, Can and Mucella, 2008, Jose et al., 2005, Lesley and Glyn, 1994,).

Table 11. Results of the presents study compared with earlier studies

\begin{tabular}{lcccccc}
\hline \multirow{2}{*}{ CSF } & \multicolumn{5}{c}{ Weights } \\
\cline { 2 - 7 } & Present study & $\begin{array}{c}\text { Previous studies } \\
\text { Sepahvand } \\
\text { and } \\
\text { Arefnezhad } \\
(2013)\end{array}$ & $\begin{array}{c}\text { Alexander } \\
(2011)\end{array}$ & $\begin{array}{c}\text { Can and } \\
\text { Mucella, } \\
(2008)\end{array}$ & $\begin{array}{c}\text { Jose et al } \\
(2005)\end{array}$ & $\begin{array}{c}\text { Lesley } \\
\text { and Glyn } \\
(1994)\end{array}$ \\
\hline Information quality & 0.2492 & 0.3860 & 0.2670 & - & 0.5320 & - \\
\hline Perceived ease of use & 0.2251 & - & 0.2580 & - & 0.1530 & 0.3700 \\
\hline System reliability & 0.1641 & 0.3100 & 0.2210 & - & - & 0.1200 \\
\hline Perceived usefulness & 0.1125 & 0.0590 & - & 0.3157 & - & - \\
\hline Top management support & 0.0944 & - & - & 0.1464 & 0.0840 & - \\
\hline Facilitating conditions & 0.0472 & - & - & - & 0.0660 & 0.0200 \\
\hline Attitude & 0.0399 & - & - & - & - & - \\
\hline Training & 0.0270 & - & - & - & - & - \\
\hline Service care quality & 0.0252 & - & - & - & - & - \\
\hline Self efficacy & 0.0106 & - & - & 0.0436 & - & - \\
\hline Other Factors considered & - & 0.2450 & 0.2540 & 0.4943 & 0.1650 & 0.4900 \\
\hline
\end{tabular}

\section{Managerial implications}

The practical implications of the study are as enumerated below. With the help of this study, the healthcare IS professionals become aware of the existence of CSF in HIS implementation along with their order of importance. AHP helps in quantifying subjective judgments of the users and gives numerical results which can be used by the healthcare IS professionals effectively. Ranking of CSF helps evaluation of HIS implementation in a more scientific way. Using this framework, the healthcare IS professionals will be able to identify the required capabilities and necessary

International Symposium of the Analytic Hierarchy

Process June 29 - July 2, 2014 
resources in order to attain and sustain competitive advantage by developing more useful and productive HIS. Many times due to the lack of sufficient resources, it is not possible for the healthcare and IS professionals to deal with all CSF at the same time. So, with the prioritization of CSF, the IS developers and healthcare professionals will be able to realize that on which factors they have to work on the priority basis to achieve greater improvements in terms of productivity. Therefore, while designing the improvement plans, this relative importance can be very helpful for the organizations at the time of facing scarcity of resources. This model also can be used by the healthcare professionals for ranking different HIS implementations across different hospitals in a region or across different vendors supplying HIS.

\section{Discussion and conclusions}

Based on the exhaustive literature review of success factors for HIS, four categories of success factors are identified. AHP method for ranking critical success factors is used that ensures consistency measure of results. By using AHP which is a multi-criteria decision making technique, some inconsistencies may arise, giving way for reconsideration of judgements and unveiling some unclear thinking regarding the assessments of some of the attributes. However, this technique has not traditionally been applied for the analysis of CSF related with HIS. The results reveal the respondents' perceptions about the importance of CSF in HIS. This is a main issue, since it is possible to manage the development process with more information about the expectations of final users. From the analysis of AHP evidences, the study verified that the system factors and behavioural intention to use factors get higher values and ranks than organisational and individual factors. The most important finding that, information quality, perceived ease of use, system reliability and perceived usefulness are higher priority CSF in information systems is verified again here in this study too. The weights associated to these factors are higher than the priority of all the rest put-together. In general, this study confirms that organisational and individual factors are less critical than system and behaviour intention to use factors and is in line with the results found in literature. The weights for the different factors obtained by using the AHP can be subsequently used to rank different HIS implementations as shown in the hierarchy level four. This can be done using different techniques. For example, an index for each HIS implementation can be calculated simply by finding weighted sum of all factors for each HIS, namely, HIS A, HIS $\mathrm{B}$ and HIS C. The critical success factors priority scores will be used to weigh the specific value of each factor for each of the different HIS in such comparisons to finalize the index score for comparison between implementations.

\section{References}

Alexander Benlian, Is traditional, open-source, or on-demand first choice? Developing an AHPbased framework for the comparison of different software models in office suites selection, European Journal of Information Systems (2011) 20, 542-559.

Al Farsi, M., and West, D. J., Jr., Use of electronic medical records in Oman and physician satisfaction. J. Med. Syst. 30:17-22, 2006.

Alquraini, H., Alhashem, A.M., Shah, M.A., Chowdhury, R.I., Factors influencing nurse's attitudes towards the use of computerized health information systems in Kuwaiti hospitals, J. Adv. Nurs. 57 (4) (2007) 375-378.

Barbeite, F.G., E.M. Weiss, Computer self-efficacy and anxiety scales for an Internet sample: testing measurementequivalence of existing measures and development of newscales, Comput. Hum. Behav. 20 (1) (2004) 1-15.

Barsukiewicz, C. K., Computerized medical records: physician response to new technology. The Pennsylvania State University, Pennsylvania, 1998.

Bedard, J.C., C. Jackson, M.L. Ettredge, K.M. Johnstone, The effect of training on auditors' acceptance of an electronic work system, Int. J. Account. Inform. Syst. 4 (2003) 227-250. 
IJAHP Article: Mu, Saaty/A Style Guide for Paper Proposals To Be Submitted to the International Symposium of the Analytic Hierarchy Process 2014, Washington D.C., U.S.A.

Bhattacherjee, A., \& Hikmet, N. (2008). Reconceptualizing organizational support and its effect on information technology usage: evidence from the health care sector. The Journal of Computer Information Systems, 48(4), 69-75.

Brady, M. K., Cronin, J. J., \& Brand, R. R. (2002). Performance-only measurement of service quality: A replication and extension. Journal of Business Research, 55(1), 17-31. doi:10.1016/S0148- 2963(00)00171-5

Buss, M.D.J., 1983. How to rank computer projects. Harvard Business Review 61 (1), 118-125.

Can U " nal and Mu" cella G. Gu"ner, Selection of ERP suppliers using AHP tools in the clothing industry, International Journal of Clothing Science and Technology, Vol. 21 No. 4, 2009, pp. 239-251.

Chau, P. (2001). Influence of computer attitude and self-efficacy on IT usage behavior. Journal of End User Computing, 13(1), 26-33.

Cheng, G. Y., Educational workshop improved information seeking skills, knowledge, attitudes and the search outcome of hospital clinicians: a randomised controlled trial. Health Info. Libr. J. 20(Suppl 1):22-33, 2003.

Chin, K. S., Xu, D. L., Yang, J. B., \& Lam, J. P. K. (2008). Group-based ER-AHP system for product project screening. Expert Systems with Applications, 35(4), 1909-1929.

Chisolm, D. J., McAlearney, A. S., Veneris, S., Fisher, D., Holtzlander, M., and McCoy, K. S., The role of computerized order sets in pediatric inpatient asthma treatment. Pediatr. Allergy Immunol. 17:199-206, 2006.

Connelly, D. P., Werth, G. R., Dean, D. W., Hultman, B. K., and Thompson, T. R., Physician use of an NICU laboratory reporting system. Proc. Annu. Symp. Comput. Appl. Med. Care. 8-12, 1992.

Crosson, J. C., Isaacson, N., Lancaster, D., McDonald, E. A., Schueth, A. J., DiCicco-Bloom, B., Newman, J. L., Wang, C. J., and Bell, D. S., Variation in electronic prescribing implementation among twelve ambulatory practices. J. Gen. Intern. Med. 23:364- 371, 2008.

Crowe, B., and Sim, L., Implementation of a radiology information system/picture archiving and communication system and an image transfer system at a large public teaching hospital Assessment of success of adoption by clinicians. J. Telemed. Telecare 10:25-27, 2004.

Cumbers, B. J., and Donald, A., Using biomedical databases in everyday clinical practice: the Front-Line Evidence-Based Medicine project in North Thames. Health Libr. Rev. 15:255265, 1998.

D’Alessandro, D. M., Kreiter, C. D., and Peterson, M. W., An evaluation of information-seeking behaviors of general pediatricians. Pediatrics 113:64-69, 2004.

DeLone, W. H., E.R. McLean, The DeLone and McLean model of information systems success: a ten-year update, Journal ofManagement Information Systems 19 (4) (2003).

Di Pietro, T., Coburn, G., Dharamshi, N., Doran, D., Mylopoulos, J., Kushniruk, A., Nagle, L., Sidani, S., Tourangeau, A., Laurie- Shaw, B., Lefebre, N., Reid-Haughian, C., Carryer, J., and McArthur, G., What nurses want: diffusion of an innovation. J. Nurs. Care Qual. 23:140-146, 2008.

Eley, D., Hegney, D., Wollaston, A., Fahey, P., Miller, P., McKay, M., and Wollaston, J., Triage nurse perceptions of the use, reliability and acceptability of the Toowoomba Adult Triage Trauma Tool (TATTT). Accident Emerg. Nurs. 13:54-60, 2005.

Firby, P. A., Luker, K. A., and Caress, A. L., Nurses' opinions of the introduction of computerassisted learning for use in patient education. J. Adv. Nurs. 16:987-995, 1991.

Galligioni, E., Berloffa, F., Caffo, O., Tonazzolli, G., Ambrosini, G., Valduga, F., Eccher, C., Ferro, A., and Forti, S., Development and daily use of an electronic oncological patient record for the total management of cancer patients: 7 years' experience. Ann. Oncol. 20:349-352, 2009.

Gillingham, W., A. Holt, J. Gillies, Hand-held computers in health care:what software programs are available? The New Zealand Medical Journal 115 (1162) (2002). 
IJAHP Article: Mu, Saaty/A Style Guide for Paper Proposals To Be Submitted to the International Symposium of the Analytic Hierarchy Process 2014, Washington D.C., U.S.A.

Goodhue, D. L., \& Thompson, R. L. (1995). Task-technology fit and individual performance. Manage $\neg$ ment Information Systems Quarterly, 19(2), 213-236. doi:10.2307/249689

Hains, I. M., Fuller, J. M., Ward, R. L., and Pearson, S. A., Standardizing care in medical oncology: are Web-based systems the answer? Cancer 115:5579-5588, 2009.

Hanafizade, P., Ghafori Rayni, S.A., 2007 "Critical Success Factor in Enterprise Strategic Planning for Information Systems ", Iran Economic Bulletin, Vol. 7 No. 26.

Hasan, B., The influence of specific computer experiences on computer self-efficacy beliefs, Comput. Hum. Behav. 19 (4) (2003) 443-450.

Haynes, R. B., McKibbon, K. A., Walker, C. J., Ryan, N., Fitzgerald, D., and Ramsden, M. F., Online access to MEDLINE in clinical settings. A study of use and usefulness. Ann Intern Med. 112:78-84, 1990.

Hier, D. B., Rothschild, A., LeMaistre, A., and Keeler, J., Differing faculty and housestaff acceptance of an electronic health record one year after implementation. Medinfo 11:1300 1303, 2004.

Hortman, P.A., Thompson, C.B., Evaluation of user interface satisfaction of a clinical outcomes database, Comput. Inform. Nurs. 23 (6) (2005) 301-307.

Hou, I. C., Chang, P., and Wang, T. Y., Qualitative analysis of end user computing strategy and experiences in promoting nursing informatics in Taiwan. Stud. Health Technol. Inform. 122:613-615, 2006.

Igbaria, M., \& Iivari, J. (1995). The effects of self-efficacy on computer usage. Omega International Journal of Management Science, 23(6), 587-605. doi:10.1016/03050483(95)00035-6

Ioannis N. Lagoudis*, Maria B. Lekakou and Helen A. Thanopoulou, Evaluating ferry services through an AHP estimated KPI system: a focus on central Aegean, Int. J. Decision Sciences, Risk and Management, Vol. 3, Nos. 1/2, 2011.

Joos, D., Chen, Q., Jirjis, J., and Johnson, K. B., An electronic medical record in primary care: impact on satisfaction, work efficiency and clinic processes. AMIA Annu. Symp. Proc. 394 398, 2006.

Jose L. Salmeron, Ines Herrero, An AHP-based methodology to rank critical success factors of executive information systems, Computer Standards \& Interfaces 28 (2005) $1-12$

Jousimaa, J., Kunnamo, I., and Makela, M., An implementation study of the PDRD primary care computerized guidelines. Scand. J. Prim. Health Care 16:149-153, 1998.

Kamadjeu, R. M., Tapang, E. M., and Moluh, R. N., Designing and implementing an electronic health record system in primary care practice in sub-Saharan Africa: a case study from Cameroon. Inform. Prim. Care. 13:179-186, 2005.

Keshavjee, K., Troyan, S., Holbrook, A. M., and VanderMolen, D., Measuring the success of electronic medical record implementation using electronic and survey data. Proc. AMIA Symp. 309-313, 2001.

Ketelhohn,W.,1998 "What is a key success factor?" European Management Journal, Vol. 16, No.3, and pp: 335-40.

Kouri, P., Turunen, H., and Palomaki, T., 'Maternity clinic on the net service' and its introduction into practice: experiences of maternity-care professionals. Midwifery 21:177-189, 2005.

Lai, F., Macmillan, J., Daudelin, D. H., and Kent, D. M., The potential of training to increase acceptance and use of computerized decision support systems for medical diagnosis. Hum. Fact. 48:95-108, 2006.

Lai, V.S., Trueblood, R.P., Wong, B.K., 1999. Software selection: A case study of the application of the analytical hierarchical process to the selection of a multimedia authoring system. Information \& Management 36, 221-232.

Lapointe, L., and Rivard, S., Getting physicians to accept new information technology: insights from case studies. Can. Med. Assoc. J. 174:1573-1578, 2006.

Larcher, B., Arisi, E., Berloffa, F., Demichelis, F., Eccher, C., Galligioni, E., Galvagni, M., Martini, G., Sboner, A., Tomio, L., Zumiani, G., Graiff, A., and Forti, S., Analysis of user 
satisfaction with the use of a teleconsultation system in oncology. Med. Inform. Internet Med. 28:73-84, 2003.

Lee, J.W., Kim, S.H., 2000. Using analytic network process and goal programming for interdependent information system project selection. Computers \& Operations Research 27, $367-382$.

Lee, T. T., Mills, M. E., and Lu, M. H., The multimethod evaluation of a nursing information system in taiwan. Comput. Inform. Nurs. 27:245-253, 2009.

Lee, T.T., Lee, T.Y., Lin, P.C., Chang, Factors affecting the use of nursing information systems in Taiwan, J. Clin. Nurs. 50 (2) (2005) 170-178.

Lee, T.T., Yeh, C.H., Ho, L.H., Application of a computerized nursing care plan system in one hospital: Experiences of ICU nurses in Taiwan, J. Adv. Nurs. 39 (1) (2002) 61-67.

Lesley Davis and Glyn Williams, Evaluating and Selecting Simulation Software Using the Analytic Hierarchy Process, Integrated Manufacturing Systems, Vol. 5 No. 1, 1994, pp. 23-32.

Likourezos, A., Chalfin, D. B., Murphy, D. G., Sommer, B., Darcy, K., and Davidson, S. J., Physician and nurse satisfaction with an Electronic Medical Record system. J. Emerg. Med. 27:419-424, 2004.

Lu, Y, Y. Xiao, A. Sears, J. Jacko, Review and a framework of handheld computer adoption in healthcare, International Journal of Medical Informatics 74 (5) (2005).

Lucas, H.C., Moore Jr., J.R., 1976. A multiple-criterion scoring approach to information system project selection. Infor. 14 (1), 1-12.

Magrabi, F., Westbrook, J. I., and Coiera, E. W., What factors are associated with the integration of evidence retrieval technology into routine general practice settings? Int. J. Med. Inform. 76:701-709, 2007.

Marcy, T. W., Kaplan, B., Connolly, S. W., Michel, G., Shiffman, R. N., and Flynn, B. S., Developing a decision support system for tobacco use counselling using primary care physicians. Inform. Prim. Care. 16:101-109, 2008.

Martinez, M. A., Kind, T., Pezo, E., and Pomerantz, K. L., An Evaluation of community health center adoption of online health information. Health Promot. Pract. 2007.

Mehmert, P.A., Dickel, C.A., Mckeighen, R.J., Computerizing nursing diagnosis, Nurs. Manage. 20 (7) (1989) 24-30.

Ngai, E. W. T., \& Chan, E. W. C. (2005). Evaluation of knowledge management tools using AHP. Expert Systems with Applications, 29(4), 889-899.

O'Connell, R. T., Cho, C., Shah, N., Brown, K., and Shiffman, R. N., Take note(s): differential EHR satisfaction with two implementations under one roof. J. Am. Med. Inform. Assoc. 11:43-49, 2004.

Ovretveit, J., Scott, T., Rundall, T. G., Shortell, S. M., and Brommels, M., Improving quality through effective implementation of information technology in healthcare. Int. J. Qual. Health Care 19:259-266, 2007.

Pagliari, C., Clark, D., Hunter, K., Boyle, D., Cunningham, S., Morris, A., and Sullivan, F., DARTS 2000 online diabetes management system: formative evaluation in clinical practice. J. Eval. Clin. Pract. 9:391-400, 2003.

Pare, G., Sicotte, C., and Jacques, H., The effects of creating psychological ownership on physicians' acceptance of clinical information systems. J. Am. Med. Inform. Assoc. 13:197205, 2006.

Popernack, M. L., A critical change in a day in the life of intensive care nurses: rising to the echallenge of an integrated clinical information system. Crit. Care Nurs. Q. 29:362-375, 2006.

Pourasghar, F., Malekafzali, H., Koch, S., and Fors, U., Factors influencing the quality of medical documentation when a paperbased medical records system is replaced with an electronic medical records system: an Iranian case study. Int. J. Technol. Assess. Health Care 24:445451, 2008. 
Pugh, G. E., and Tan, J. K., Computerized databases for emergency care: what impact on patient care? Methods Inf. Med. 33:507-513, 1994.

Rahimi, B., Timpka, T., Vimarlund, V., Uppugunduri, S., and Svensson, M., Organization-wide adoption of computerized provider order entry systems: a study based on diffusion of innovations theory. BMC Med. Inform. Decis. Mak. 9:52, 2009.

Saaty, R.W. (1987) 'The analytic hierarchy process-what it is and how it is used', Mathematical Modelling, Vol. 9, Nos. 3-5, pp.161-176.

Saaty, T. L. (1994). How to make decision: the analytical hierarchy process. Interfaces, 24(6), 1943.

Saaty, T. L. (1996). The analytic hierarchy process: Planning, priority setting, resource allocation (2nd Ed.), Pittsburg, PA: RWS Publications.

Saaty, T. L. (2008). Decision making with analytic hierarchy process. International Journal of Services Sciences, 1(1), pp. 83-98

Saaty, T.L. and Vargas, L.G. (2000). Models, Methods, Concepts and Applications of the Analytic Hierarchy Process, Boston: Kluwer Academic Publishers.

Saaty, T.L., 1980. The Analytic Hierarchy Process. McGraw- Hill, New York

Santhanam, R., Kyparisis, G.J., 1995. A multiple criteria decision model for information system project selection. Computers \& Operations Research 22 (8), 807-818.

Sarker, S., J.S. Valacich, S. Sarker, Technology adoption by groups: a valence perspective, Journal of the Association for Information Systems 6 (2) (2005).

Schniederjans, M.J., Wilson, R.L., 1991. Using the analytic hierarchy process and goal programming for information system project selection. Information \& Management 20, 333342.

Seddon, P. B., \& Kiew, M. Y. (1996). A partial test and development of DeLone and McLean's model of IS success. Australian Journal of Information Systems, 4(1), 90-109.

Sepahvand, R., Arefnezhad, M., Prioritization of Factors Affecting the Success of Information Systems with AHP (A Case study of Industries and Mines Organization of Isfahan Province), International Journal of Applied Operational Research Vol. 3, No. 3, pp. 67-77, Summer 2013.

Simpson, C.A., Weaver, R.L., Administrative application of information technology for nursing managers, in: V.K. Saba, K.A. McCormick (Eds.), Essentials of nursing informatics, McGraw Hill, Boston, 2005.

Soar, J., Ayres, D., and Van der Weegen, L., Achieving change and altering behaviour through direct doctor use of a hospital information system for order communications. Aust. Health Rev. 16:371-382, 1993.

Stahl, Michael J, Encyclopedia of health care management, Sage Publications, 2004.

Sutirtha Chatterjee, Suranjan Chakraborty, Saonee Sarker, Suprateek Sarker, Francis Y. Lau, xamining the success factors for mobile work in healthcare: A deductive study, Decision Support Systems 46 (2009) 620-633

Teltumbde, A., 2000. A framework of evaluating ERP projects. International Journal of Production Research 38, 4507-4520.

Thoman, J., Struk, C., Spero, M. O., and Stricklin, M. L., Reflections from a point-of-care pilot nurse group experience. Home Healthc. Nurs. 19:779-784, 2001.

Torkzadeh, G., T.P. Van Dyke, Effects of training on Internet self-efficacy and computer user attitudes, Comput. Hum. Behav. 18 (5) (2002) 479-494.

Travers, D., and Parham, T., Improving information access with an emergency department system. Proc. AMIA Annu. Fall Symp.121-125, 1997.

Tsai, Y.J., Wu, S., Chiang, B.C., Exploring factors affecting the performance of hospital information systems, J. Inf. Manage. 11 (2) (2004) 191-210.

Vanmeerbeek, M., Exploitation of electronic medical records data in primary health care. Resistances and solutions. Study in eight Walloon health care centres. Stud. Health Technol. Inform.110:42-48, 2004. 
IJAHP Article: Mu, Saaty/A Style Guide for Paper Proposals To Be Submitted to the International Symposium of the Analytic Hierarchy Process 2014, Washington D.C., U.S.A.

Varshney, U., Pervasive healthcare, Computer 36 (2) (2003).

Venkatesh, V., \& Davis, F. D. (2000). A theoretical extension of the technology acceptance model: Four longitudinal field studies. Management Science, 46(2), 186-204. doi: $10.1287 / \mathrm{mnsc} .46 .2 .186 .11926$

Venkatesh, V., Morris, M. G., Davis, G. B., \& Da $\urcorner$ vis, F. D. (2003). User acceptance of information technology: Toward a unified view. Management Information Systems Quarterly, 27(3), 425-478.

Verhoeven, F., Steehouder, M. F., Hendrix, R. M., and van Gemert-Pijnen, J. E., Factors affecting health care workers' adoption of a website with infection control guidelines. Int. J. Med. Inform. 78:663-678, 2009.

Walji, M. F., Taylor, D., Langabeer, J. R., 2nd, and Valenza, J. A., Factors influencing implementation and outcomes of a dental electronic patient record system. J. Dent. Educ. 73:589-600, 2009

Whittaker, A. A., Aufdenkamp, M., and Tinley, S., Barriers and facilitators to electronic documentation in a rural hospital. J. Nurs. Scholarsh. 41:293-300, 2009.

Wu, S, Lee, A., Tah, J.H.M. and Aouad, G., The use of a multi-attribute tool for evaluating accessibility in buildings: the AHP approach, Facilities, Vol. 25 No. 9/10, 2007, pp. 375-389.

Yeh, S. H., Jeng, B., Lin, L.W., Ho, T. H., Hsiao, C. Y., Lee, L. N., and Chen, S. L., Implementation and evaluation of a nursing process support system for long-term care: a Taiwanese study. J. Clin. Nurs. 18:3089-3097, 2009.

Zheng, K., Padman, R., Johnson, M. P., and Diamond, H. S., Understanding technology adoption in clinical care: clinician adoption behavior of a point-of-care reminder system. Int. J. Med. Inform. 74:535-543, 2005. 